\title{
Nevoid basal cell carcinoma (Gorlin) syndrome
}

Robert J. Gorlin

When students ask me how I ever came to such a strange field as syndromes, I never hesitate to tell them my story of pure serendipity. It was a matter simply of hearing the right lecture at the right time.

As I recall, Columbia Presbyterian Medical Center was not a hot bed of liberalism during the 1940s. Helen Ollendorf Curth was a famous and highly qualified dermatologist. She had come to New York City to escape the Holocaust. At that time, she had no appointment to Columbia's Dermatology Department. In Berlin, she and Professor A. Buschke had described many disorders, including a syndrome of connective tissue nevi and bones that looked as if candle wax were dripped on them (Buschke-Ollendorf syndrome). An invitation came for Helen to give a lecture at Columbia on Helen's favorite disease, acanthosis nigricans. Although we now know that acanthosis nigricans represents a nonspecific keratinocyte proliferation secondary to inter alias, a deficiency of insulin-binding receptors, in the late 1940s, we were only in the clinically descriptive stage. Based upon her experience, Helen divided acanthosis nigricans into an autosomal dominant "benign" form, a pseudoacanthosis nigricans seen in rather obese brunettes, a nongenetic so-called malignant acanthosis nigricans, and a miscellaneous group that included various associated endocrinopathies and a Crouzon-like disorder that we now know as Crouzonodermoskeletal dysplasia.

I was transfixed, listening to her expand on what she called the "malignant" form of acanthosis nigricans. By that term, Helen meant the occurrence of hyperplastic skin on the neck, lips, tongue, flexural sites, inframammary areas, umbilicus, axillae, groin, palms, etc. of patients in association with "gastric adenocarcinoma." Skin lesions appeared dark and studded with acrochordon-like excrescences. The concept that there could be cutaneous and mucosal signs of internal malignancy was something I had never encountered before-I was captured.

After the talk, I approached Helen and asked her what these associations were called. "Syndromes," she answered in her delightful Berliner accent. "'Syn' means 'together' and 'drome, drome, drome'-I forget. Why don't you look that up!” I found a medical dictionary and returned a minute or two later. "Run, run together," I offered.

"You could do me a great favor and tell me about other syndromes that affect the face and mouth as I am a dentist."

From the Oral Sciences-Oral Pathology, University of Minnesota School of Dentistry, Minneapolis, Minnesota.

Robert J. Gorlin, Oral Sciences-Oral Pathology, University of Minnesota Dentistry, Minneapolis MN 55455.

DOI: 10.1097/01.GIM.0000144188.15902.C4
"Good Lord, a dentist, what are you doing in a course in dermatopathology?" I went on to explain how I was trying to expose myself to areas of learning that would help bolster my belief that oral pathology should be less dental pathology and more oral manifestations of systemic disease. As I said above, I was captured, raptured, and had a sort of religious experience-an apotheosis—-this would be my field.

\section{NEVOID BASAL CELL CARCINOMA SYNDROME}

In large part, it was chance that determined that I volunteered to help a friend who wished to go on vacation in 1958, two years after I came to Minnesota. I promised to sit in his Minneapolis dental office on Saturday mornings and take care of "emergencies." No real emergencies presented themselves-but I received a phone call from a woman who wanted me to "x-ray her jaws for those pesky cysts." After several minutes of inquiry, I determined that she had 20 to 30 cysts removed from both jaws dating from the age of 7 years. This unusual story greatly roused my curiosity because I could not imagine what type of cysts they might be. The patient told me that she was not much more than 39 , that she had several cysts removed at the University of Minnesota School of Dentistry, and that her dentist in the "early days" had been Dr. Daniel Ziskin, oddly enough my mentor at Columbia University Dental School during my fellowship days.

Following our phone conversation, I called my oral pathology laboratory and found that one of my graduate students, Dr. Nat Rowe, was working on his MS thesis that Saturday afternoon. After I told him the story, Nat repaired to the laboratory, found myriad slides of jaw cysts removed from my patient, examined them, and told me that they "looked boringly uniform." He added that the epithelium seemed to pull away from the underlying connective tissue. That description did not help me much at the time but he was correct, they were odontogenic keratocysts—a term not then used. I believe they were called primordial cysts in 1960.

I arranged to see the patient the following Saturday morning. She was a middle-aged woman with macrocephaly, distinct kyphosis, and several small lesions scattered about her face that looked to me like basal cell carcinomas. She wore a prosthetic left eye due to "some congenital defect." As she predicted, there were several new jaw cysts present. I suggested a biopsy of one or more of these skin lesions, perhaps by my colleague, Dr. Robert Goltz, a rising star in our Department of Dermatology.

After discussing the matter with her cousin, a well-known investigator from Chicago in mucopolysaccharide research, she consented. In the interim, puzzled by her disorder, I gar- 
nered records and radiographs from several hospitals where she had been treated for various problems over the years. I noted that she had calcification of the falx cerebri, several bifid and splayed ribs, and pelvic calcification.

Searching the literature on combinations of jaw cysts, rib anomalies, and basal cell carcinomas, I came up almost empty handed. However, in a recently published AFIP fascicle on skin tumors, I found a picture of a woman who I suspected had the same disorder as my patient. She had a similarly affected child. This information, suggesting dominant inheritance, caused me to search the literature once more for inherited basal cell carcinomas. The yield wasn't much better. And my patient was unmarried and was not likely to change her status. She stated that no one in her family had stigmata of the syndrome. I suspect it was out of frustration that Dr. Jorge Yunis and I karyotyped my patient, not suspecting that we would find anything but were astonished to discover an "uncoiler chromosome 1," as it was then called, an unrelated polymorphism that on subsequent investigation ran through her family in an autosomal-dominant manner. Of note, it was not until a few years ago that I was informed that the sister of my proposita began to exhibit the first signs of the syndrome at age 55 . This implied that one of their parents was affected-a confounding aspect of the story.

After amassing as much data as we could and with further literature search back to 1880, Bob Goltz and I wrote "Multiple Nevoid Basal Cell Epitheliomata, Jaw Cysts, Bifid Rib-a Syndrome," which was published in New England Journal of Medicine $1960 .{ }^{1}$ If there was any effect from that article, it was mostly on me. The little ripples it caused were in the form of letters from various dermatologists who "had seen similar cases." It was in this way that I met Jim Howell, MD, of Dallas, Texas, who contributed greatly to our understanding of the disorder.

Cases of the syndrome continued to accumulate and in $1963,1965,1970,1971,1972$, and 1987, I published reviews of the disorder. In the 43 years since our first article, several patients with the syndrome stand out in my memory. One young fellow who worked in a pet store in St. Paul was bitten by a cobra. He was rushed to the city hospital on a motorbike that crashed into a truck on the way to the emergency ward and he suffered a fractured femur. While recovering from both afflictions, it was noted that he had several basal cell carcinomas scattered over his face and I was brought in on consultation.

Another involved a phone call one January from a sheriff in Montana who wished to know whether having the disorder causes "mental aberrance," as he put it. It seems that a 16-yearold female had been told that because of bilateral ovarian fibromas (a not uncommon finding in the syndrome), she would be sterile. She became depressed and having imbibed much too much whiskey to drown her sorrow, took a header out the nearest window. Fortunately, the window was no more than six feet off the ground and she landed unhurt in a snowbank. The sheriff took her to the station to sober up. She, subsequently, claimed that he "manhandled" her. Hence, the sheriff s question. I told him that, in my experience, despite the ovarian fibromas, sterility is not a problem and that this good news should cheer her up considerably.

In the 1980s, I had numerous requests for blood from my patients for DNA studies for gene localization of nevoid basal cell carcinoma syndrome. A rather substantial corpus of correspondence ensued between me and several investigators. In August 1991, a note was received from Dr. Allen Bale of Yale inviting me to a small get-together of people interested in "Gorlin syndrome." This was to take place at the 8th International Congress of Human Genetics in Washington, DC. In my naiveté, I thought that the sharing of positive information regarding the location of the gene or even sharing negative information might be possible, but that was not to be. Within a few months, gene mapping was accomplished simultaneously by Peter Farndon et al. ${ }^{2}$ of Birmingham, André Reis et al. ${ }^{3}$ of Berlin, and Allen Bale et al. ${ }^{4}$ of New Haven. Allen also showed that the syndrome results from the uncovering of a tumor suppressor gene at this site, which explained not only the inordinate number of basal cell carcinomas but the cardiac fibromas, fetal rhabdomyomas, medulloblastomas, ovarian fibromas, lymphomesenteric cysts, and odontogenic keratocysts. The molecular aspects of the condition involving the Hedgehog pathway will be described later in this article. It is obvious that no work is done in a vacuum. Although this disorder has been named "Gorlin syndrome," perhaps because I've had such sustained interest in it, a veritable horde of investigators have contributed to its understanding.

A few words regarding nomenclature-another name such as nevoid basal cell carcinoma syndrome is misleading because only about $50 \%$ of white patients, 20 years of age or older, exhibit significant numbers of skin cancers, and only a rare one becomes aggressive. In black patients, the skin cancers often are never present. The term basal cell nevus is not acceptable because the lesions are basal cell carcinomas from the beginning and the term nevus implies a hamartomatous condition. I am personally opposed to eponyms because they say nothing about the disorder, frequently give rise to argument regarding priority of discovery, and may be chauvinistic and unfair to those whose contributions to knowledge of the syndrome far exceed those of the individuals from whom the disorder gets its name. Perhaps the disorder should be named at the molecular level, but this has its obvious problems, and I do not have a solution to the problem.

\section{EPIDEMIOLOGY}

It is likely that the condition existed during Dynastic Egyptian times because a constellation of findings compatible with the syndrome has been reported in mummies from about 1000 BC. ${ }^{5}$ Approximately $0.4 \%$ of all cases of basal cell carcinomas represent nevoid basal cell carcinoma syndrome. ${ }^{6}$ Rahbari and Mehregan ${ }^{7}$ noted that $2 \%$ of patients younger than 45 years of age with basal cell carcinomas have the syndrome. Evans et al. ${ }^{8,9}$ suggested that the minimal prevalence was 1 per 57,000. An almost identical value was noted by Pratt and Jackson. ${ }^{10}$ 


\section{CLINICAL FINDINGS}

\section{Craniofacial features}

The head appears large, i.e., $>60 \mathrm{~cm}$ in adults (See Figs. 1-7). A relative macrocephaly (occipital frontal circumference greater than 95th centile for height) is found in 50\%. ${ }^{11}$ However, hydrocephalus has been rarely present. Frontal bossing, noted in $25 \%$, may cause the eyes to appear sunken. The question has often been raised as to whether there is distinctive facies associated with the syndrome. That there is becomes evident if one attends parent support groups where
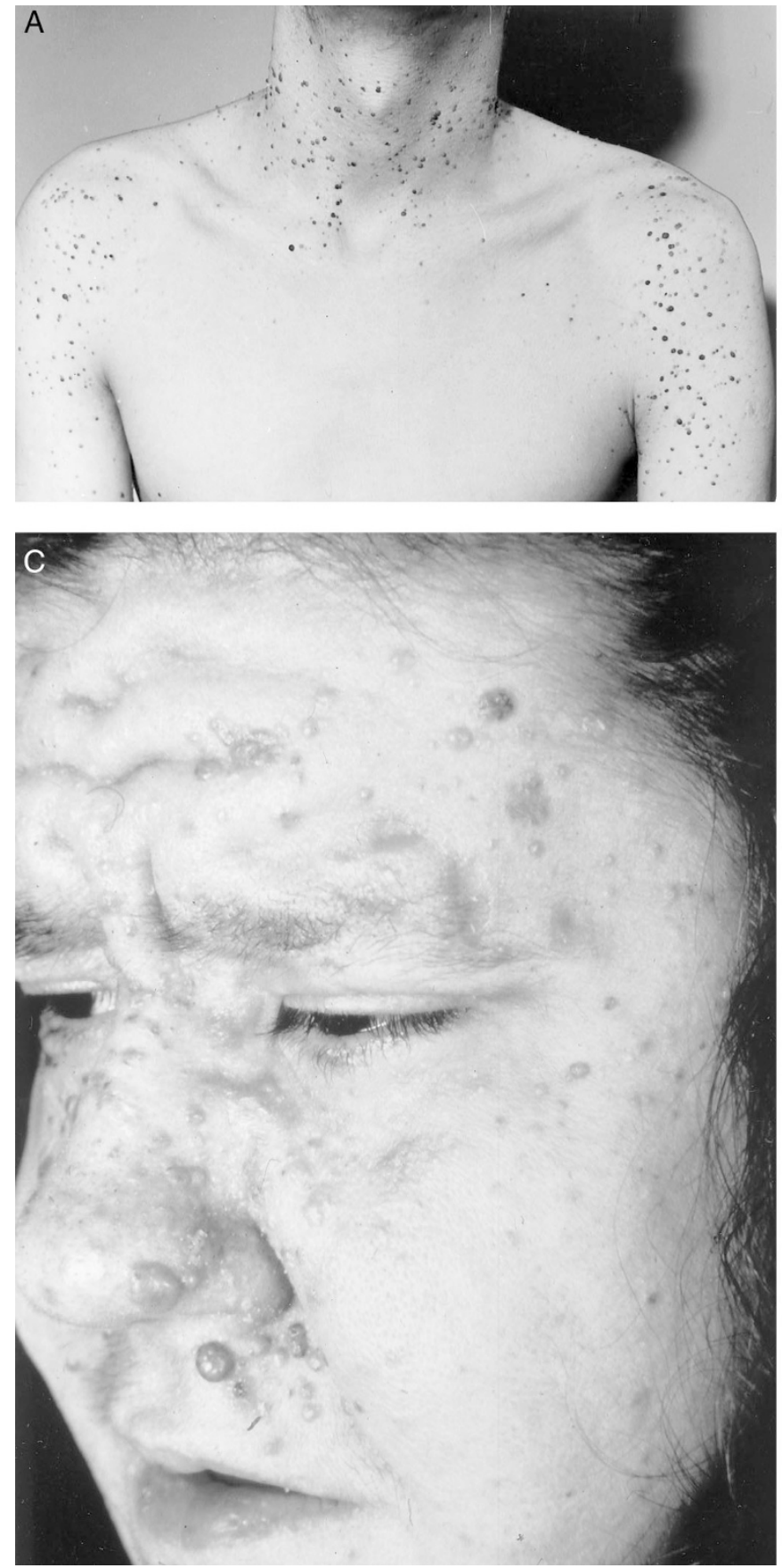

up to 100 people are in attendance. One can often note the frontal bossing and pouting lower lip. Facial milia are scattered among the basal cell carcinomas in at least $50 \%$ to $60 \%$. These are especially prominent around the eyes, eyelids, nose, malar region, and upper lip. Cleft lip and/or palate have been noted in 2-8\%.12,13

\section{Eyes}

About $10 \%$ to $25 \%$ have various ocular problems that include congenital cataract, microphthalmia, orbital cysts,

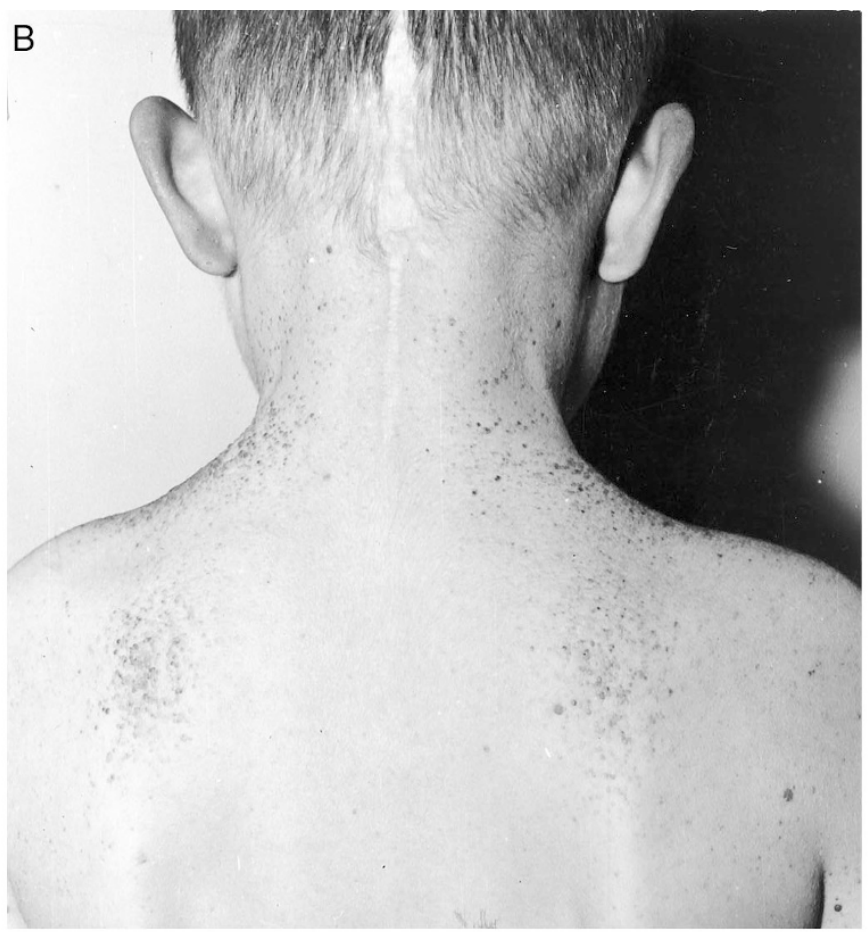

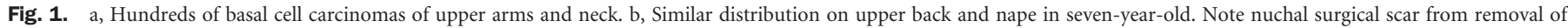
medulloblastoma. c, Numerous facial basal cell carcinomas. 


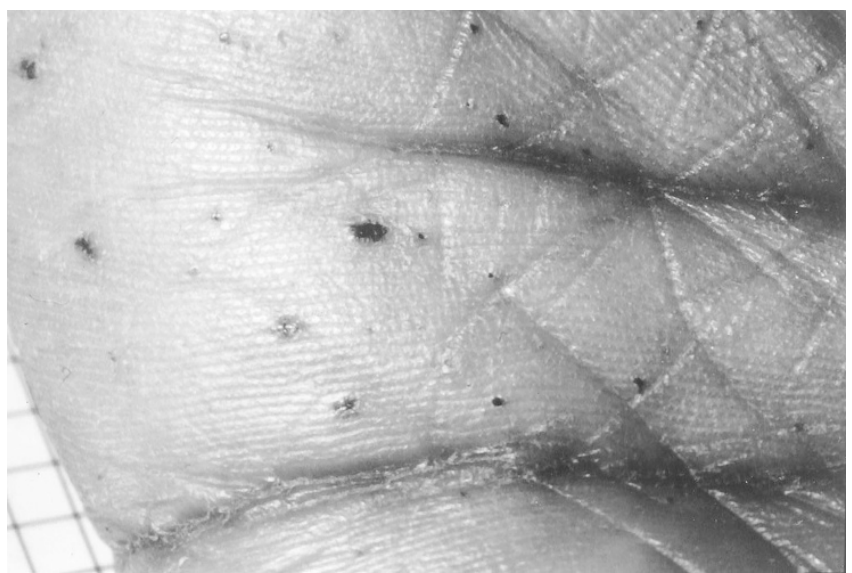

Fig. 2. Palmar pits with ingrained dirt.

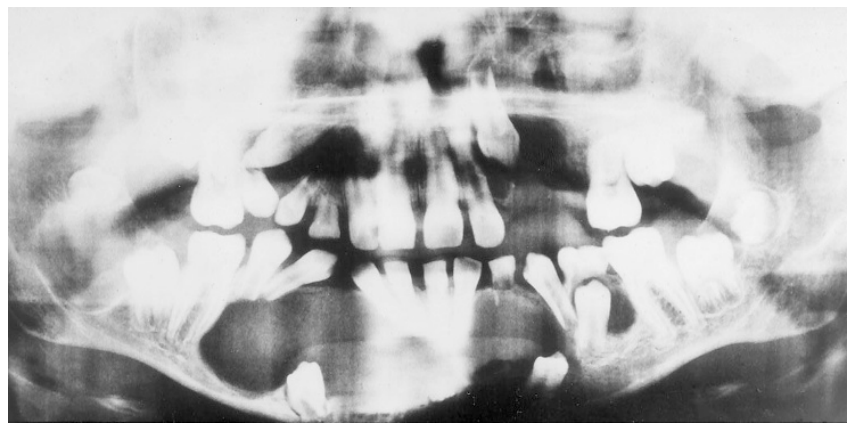

Fig. 3. Numerous odontogenic keratocysts in both mandible and maxilla.

coloboma of the iris, choroid and optic nerve, strabismus, and nystagmus. ${ }^{14-16}$ Most striking are small very transient keratinfilled cysts (milia) found on the palpebral conjunctivae in about $40 \%$. This observation is a personal one derived from a parental support group in Manchester, England. The author asked the assembled group if they ever had one or more of these transient cysts. This was repeated for an American support group for nevoid basal cell carcinoma syndrome. Because of the transient nature of these cysts, most noted that they were not significantly disturbed by their presence, but they had been to ophthalmologists who confirmed the presence of milia of the palpebral mucosa.

\section{Skin}

The most pesky aspect of the syndrome are the inordinate number of basal cell carcinomas, which appear as early as two years of age. Rarely are they found below the waist. Perhaps the most common site for their initial appearance is the nape of the neck. There is a definite proclivity for proliferation of the cancers between puberty and 35 years of age. ${ }^{17}$ The median age of onset is about 25 years. However, I have seen one patient who did not have any basal cell carcinomas until she was 55 years of age. Only about $10 \%$ of individuals with the other classic stigmata have no evident basal cell carcinomas. There is definite relationship to sun exposure and skin pigmentation. Only about $40 \%$ of African-Americans with the syndrome manifest

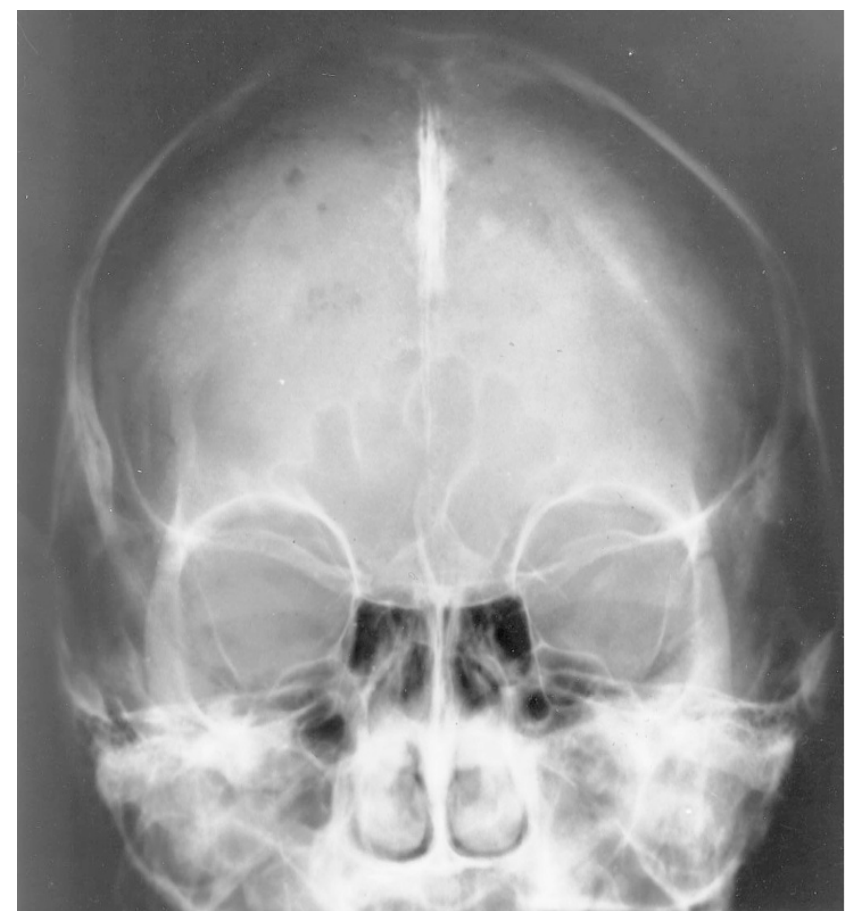

Fig. 4. Calcification of Falx cerebri.

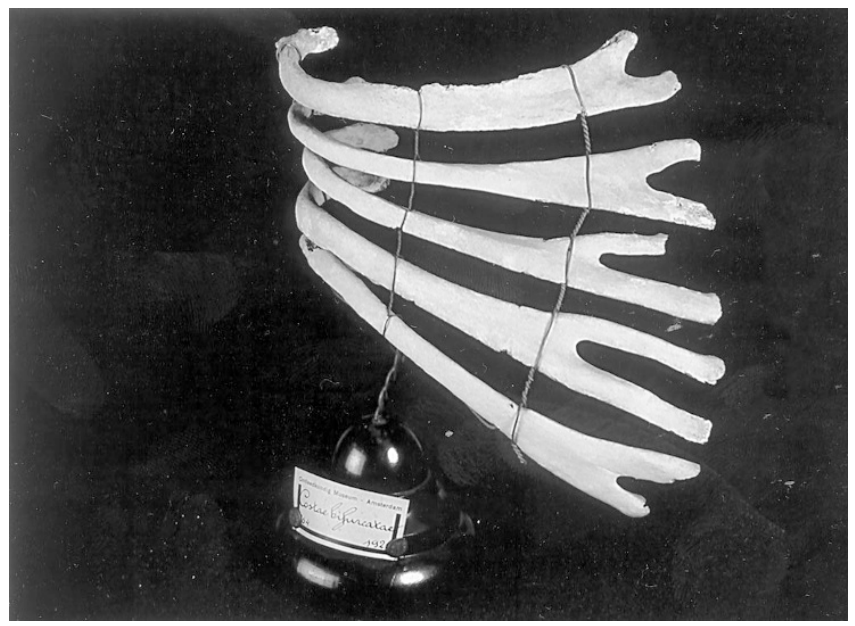

Fig. 5. Many bifid ribs. (From patient specimens noted by Raoul Hennekam, Amsterdam.)

basal cell carcinomas and even then the number of lesions is usually small in contrast to many basal cell carcinomas evident in Caucasians. ${ }^{18}$

The cancers may vary from few to thousands and range in size from 1 to $10 \mathrm{~mm}$ in diameter. They are pearly to fleshcolored to pale brown. The sites most often involved are the face, back, and chest. Most show little growth. It is only after puberty that the basal cell cancers can become aggressive and invade locally. If a lesion increases in size or begins to bleed or crust, invasion is suggested. Radiation therapy causes proliferation in the basal cell carcinomas with invasion several years later; and rarely death results from extension to the brain. In 


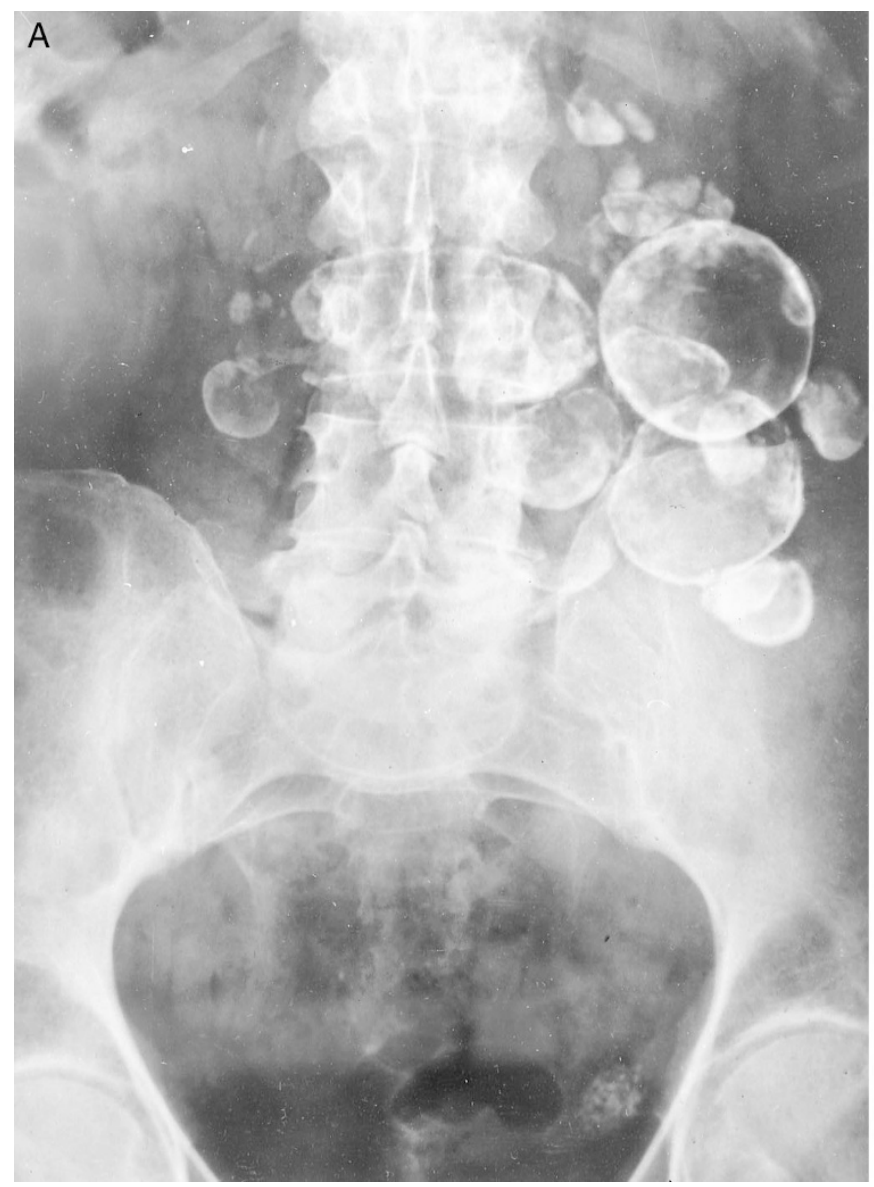

Fig. 6. a, multiple calcified lymphomesenteric cysts. b, Two lymphomesenteric cysts.

only a few cases has there been any evidence of metastasis. ${ }^{19,20}$ There are large numbers of cases in the dermatological literature relating unilateral or even quadrant involvement with basal cell carcinomas. We strongly suspect this represents somatic mutation. ${ }^{21}$

The histopathology of nevoid basal cell carcinomas cannot be differentiated from that of ordinary sporadic basal cell carcinoma. The tumors are composed of nests and islands or sheets of large, deeply-stained nuclei with indistinct cell membranes. At the periphery of each lesion, the epithelial cells are well-polarized, suggestive of cutaneous basal cells. About 30\% of NBCCS patients have two or more types of basal cell carcinoma patterns (morphea-like, solid, superficial, cystic, adenoid, fibroepithelial). Commonly (30-50\%), one sees milia intermixed with the basal cell islands, and calcified foci may be noted not only within the tumor but in normal skin. Perhaps this reflects the "turning on" of the bone morphogenetic protein gene (see Discussion).

Larger, often multiple, epidermal cysts arise on the limbs and trunk in about 35 to $50 \%$ of affected patients. As noted above, about $40 \%$ exhibit transitory multiple cysts on the palpebral conjunctiva.

Palmar and, somewhat less often, plantar pits which measure about $1-2 \mathrm{~mm}$ in diameter are asymmetrically present in

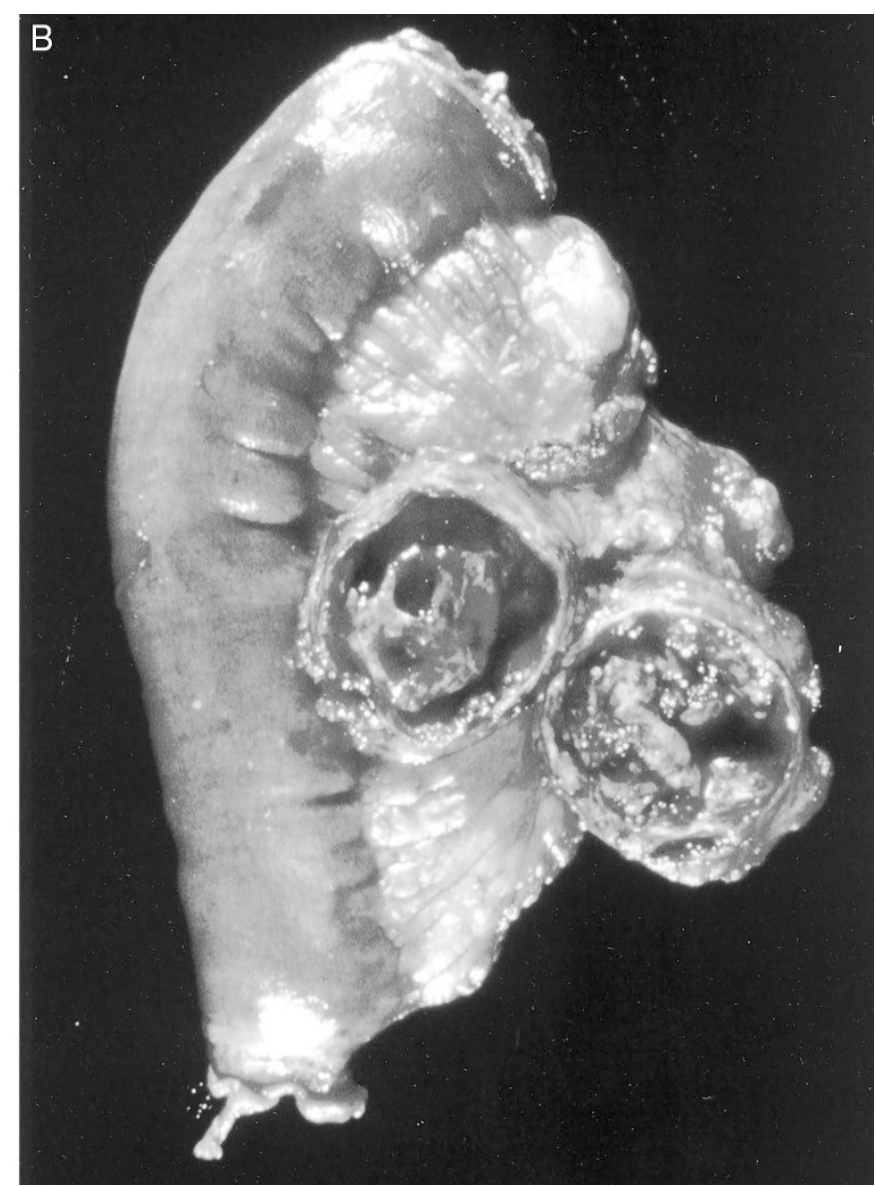

$65 \%$ to $80 \% .{ }^{17}$ They are better visualized if the patient wets the hands in warm water for ten minutes before examination. Individuals whose occupations involve manual labor may have more obvious pits because of ingrained dirt or grease. The pits may be present in children, but a careful related study is lacking. Rarely, basal cell carcinomas have arisen in these pits.

\section{Odontogenic keratocysts}

Patients with nevoid basal cell carcinoma syndrome are plagued with multiple cysts of the upper and lower jaws that may present as early as the seventh year of life. The youngestknown affected child was five years. ${ }^{22}$ The median age of appearance is about 15 years. This is at least 10 to 20 years earlier than in those with nonsyndrome keratocysts. The average number of cysts in nevoid basal cell carcinoma syndrome is 5 but has ranged from 1 to 30 . Those in the mandible are three times as common as those that present in the maxilla. Evans et al., ${ }^{15}$ in a population-based study, found odontogenic keratocysts in $90 \%$ of those over 40 years and in $80 \%$ in those over 20 years, with an overall frequency somewhat in excess of $65 \%$. They peaked during the second and third decades but continued to appear throughout the life of the patient. There is no racial predilection. Although the cysts may be extremely large, and destroy large portions of the jaws, they rarely cause symp- 


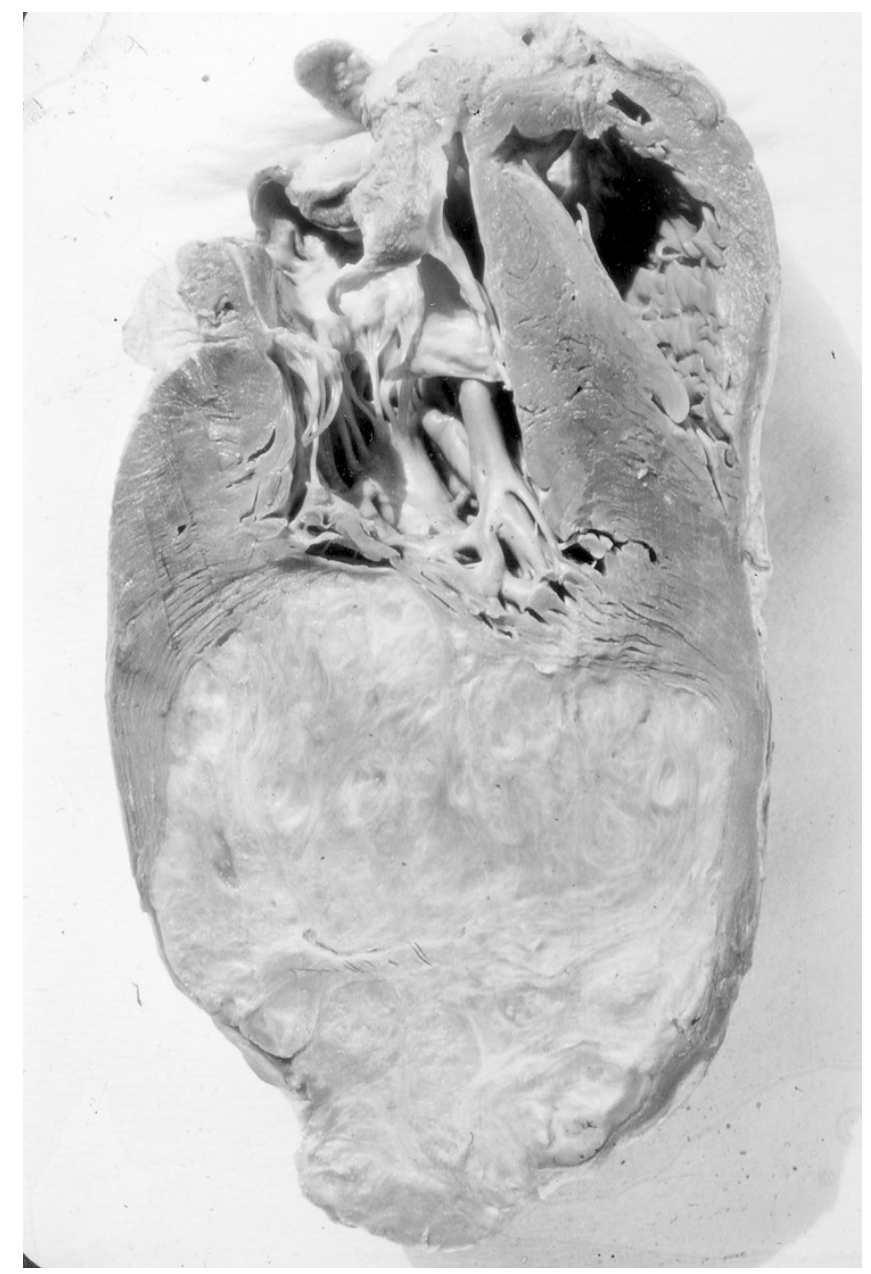

Fig. 7. Fibroma of heart.

toms but markedly effect tooth displacement. Despite this, jaw fractures almost never occur. About one-half present with swelling, a quarter with mild pain, and $15 \%$ with unusual taste following rupture of a cyst. In the maxilla, the sinuses may be invaded, and in the mandible, the cysts may even extend to the coronoid process and may cross the midline. One of the most annoying aspects is the $60 \%$ recurrence following surgery. In part, this may be due to incomplete removal, i.e., from retention of epithelial islands and/or satellite microcysts, which occur with great frequency in the connective tissue capsule or from proliferation of the basal layer of the epithelium. ${ }^{23}$

There have been a few reports of ameloblastoma arising in odontogenic keratocysts. ${ }^{24}$ Less common, squamous cell carcinoma has arisen in a cyst wall. ${ }^{25}$ The odontogenic keratocysts microscopically present as being multilocular with parakeratinized (96\%) or, rarely, orthokeratinized (4\%) stratified squamous epithelium consisting of only a few rows of cells with a well-defined basal epithelial cell layer, palisaded nuclei but no rete ridges. Budding of the epithelium into the connective tissue with suprabasalar splitting has been noted in at least $50 \%$. The cyst capsule is thin. Syndrome keratocysts tend to occur at a much earlier age than isolated keratocysts and apparently have a higher rate of postsurgical recurrence. ${ }^{26}$ Most authors believe that odontogenic keratocysts arise from the dental lamina. ${ }^{14}$

\section{Musculoskeletal and radiographic findings}

Mean height is increased $(183 \mathrm{~cm}$ in males, $174 \mathrm{~cm}$ in females). About $15 \%$ of patients are extremely tall. The calvaria tends to be large with frontal and biparietal bossing, but this appears to be correlated with height. The mandibular coronoid processes are enlarged. ${ }^{27}$

One of the most striking features of the disorder is the lamellar calcification of the falx, which is found in $55 \%$ to $95 \%$ of the population as opposed to perhaps $5 \%$ in the general population. One can also see calcification of the tentorium cerebelli in $20 \%$ to $40 \%$, of the petroclinoid ligament in $20 \%$, and of the diaphragma sellae in $60 \%$ to $80 \% .{ }^{28}$ Radiologically, this appears as if the sella turcica is bridged, i.e., as if there were fusion of the anterior and posterior clinoid processes. Agenesis of the corpus callosum, with or without lipoma, has been noted as well as "empty sella syndrome." 29

Fused, splayed, or bifid ribs have been documented in $45 \%$ to $60 \%$, and kyphosis with or without pectus deformity is noted in $40 \%$. Spina bifida occulta of the cervical or thoracic vertebrae is found in $60 \% .{ }^{30}$ However, in a series studied by Kimonis et al., ${ }^{11}$ spina bifida occulta occurred in only $20 \%$. Sprengel deformity has been observed in $10 \%$ to $40 \%$.

There has been a vast array of other skeletal anomalies. About 5\% exhibit pre- or postaxial polydactyly of hand or feet, hallux valgus, or syndactyly of fingers 2 to 3 .

Small cystic bone lesions (flame-shaped lucencies) have been identified in phalanges, metapodial bones, carpal and tarsal bones, long bones, pelvis, and calvaria in 30\%. ${ }^{31}$ Calvarial involvement may give the erroneous impression that medulloblastoma has spread to bone. ${ }^{32}$ Histologically, the flame-like lesions consist of fibrous connective tissue, nerves, and blood vessels, i.e., they are hamartomas.

\section{Medulloblastoma, other brain tumors, and seizures}

Herzberg and Wiskemann ${ }^{33}$ first pointed out the association of NBCCS with medulloblastoma in 1963. The tumor characteristically presents during the first two years of life as opposed to 7 to 8 years in the general population. The incidence of medulloblastoma was determined by Evans et al. ${ }^{15}$ to be $1 \%$ to $2 \%$ in 173 consecutive cases of the tumor. Conversely, a population study of NBCCS determined that $3 \%$ to $5 \%$ had medulloblastoma. There appears to be a $3 \mathrm{M}: 1 \mathrm{~F}$ sex predilection. Because medulloblastoma presents so early in patients with NBCCS as opposed to those in the general population, children who present with the tumor, especially those $<5$ years, should be carefully examined for signs of the syndrome. ${ }^{11}$ Examples have been almost exclusively of the desmoplastic variety. ${ }^{34}$ There is some evidence that medulloblastoma associated with NBCCS behaves more benignly than those found as isolated examples. ${ }^{34-36}$ Radiation therapy of medulloblastoma results in profuse numbers of invasive basal cell carcinomas appearing in the radiation field (i.e., from nape to base of spine). ${ }^{37} \mathrm{Clin}$ - 
ically, a "rash" appears from 6 months to 3 years after radiation therapy. The rash represents activated basal cell cancers, which often become markedly invasive within another 10 years.

Other brain tumors are infrequent. The next most common is meningioma, but other tumors have included astrocystoma, craniopharyngioma, and oligodendroglioma. These tumors may well be secondary to radiation therapy.

Cysts of the brain have been reported: colloid cyst of third ventricle, arachnoid cyst, intraparenchymal cyst, cysts of the septum pellucidum. Vermian dysgenesis has been noted in a mother and daughter. ${ }^{38,39}$

Seizures have occasionally been noted unassociated with brain tumors and possibly are due to focal neuronal heterotopia. ${ }^{40}$

\section{Ovarian fibromas and fibrosarcomas}

It is difficult to know the frequency of ovarian fibromas in NBCCS as they do not present unless they become large and calcified or twist on their pedicles. A population-based study, performed in the early 90 s, suggests that a frequency of $25 \%$ might be reliable. ${ }^{15}$ Some authors have found ovarian fibromas on ultrasound in about $15 \% .{ }^{17}$ Ovarian fibromas associated with NBCCS are most often bilateral (75\%), calcified, and nodular, often overlapping medially. A number of such cases have been erroneously diagnosed as calcified uterine leiomyomas. Those ovarian fibromas not associated with the syndrome are unilateral and calcified only $10 \%$ of the time. Rarely, the tumor may be virilizing ${ }^{41}$ or renin-secreting. ${ }^{42,43}$ Ovarian fibrosarcoma ${ }^{44}$ and primary ovarian leiomyosarcoma ${ }^{45}$ have also been reported.

\section{Mesenteric cysts}

Single or multiple chylous or lymphatic mesenteric cysts have been documented. Most examples have not produced symptoms, only having been found at laparotomy and, hence, underestimated. ${ }^{14}$ The cysts are thin-walled and measure 2 to $14 \mathrm{~cm}$ in diameter. The contents are chylous but may contain hemorrhagic turbid fluid. Microscopically, the wall is composed of fibrous connective tissue and smooth muscle. A layer of lymphatic cells are often located beneath the endothelial lining.

\section{Fetal rhabdomyoma}

Schweisguth et al. ${ }^{46}$ were the first to report fetal rhabdomyoma. In a newborn with NBCCS, several authors have described examples but at various sites. ${ }^{47-50}$ Mature striated muscle within the tumor is quite diagnostic.

\section{Kidney anomalies}

Various minor kidney anomalies are found in approximately $5 \%$. These have included horseshoe kidney, L-shaped kidney, unilateral renal agenesis, renal cyst, and duplication of renal pelvis and ureters. ${ }^{14,51}$ Because most of these anomalies have been diagnosed on laparoscopy or autopsy, the frequency is probably higher.

\section{Hypogonadism}

Perhaps $5 \%$ to $10 \%$ of males exhibit signs of hypogonadotropic hypogonadism such as anosmia, cryptorchidism, female pubic escutcheon, gynecomastia, and/or scanty facial or body hair. Shanley et al. ${ }^{17}$ noted $10 \%$ with anosmia. We are aware of two patients with classic Turner syndrome.

\section{Cardiac fibroma}

Cardiac fibromas occur with far higher frequency in the syndrome than that of chance. They have presented from birth to 60 years. Cardiac fibroma is discrete, well-circumscribed, not encapsulated, firm, gray-white, 3 to $4 \mathrm{~cm}$ in diameter, and may, upon occasion, exhibit central calcification. The tumor is most often located in the left anterior ventricular wall. If the tumor projects into the chamber, hemodynamics is impeded. One may also note conduction defects, i.e., arrhythmias due to involvement of the intraventricular septum. ${ }^{52}$ On the other hand, most, having caused no symptoms, have been discovered accidentally. As of this writing, approximately 25 examples have been reported. Evans et al., ${ }^{15}$ in a population-based study, estimated that cardiac fibromas are seen in about $3 \%$ of individuals with the syndrome. The tumors are composed of fibroblasts embedded in a dense matrix of collagen and elastic fibers.

\section{Miscellaneous other tumors}

There appears to be an increased incidence of several other neoplasms or hamartomas: leiomyomas of bowel and mesentery, leiomyosarcoma, adrenal cystic lymphangioma, thyroid adenoma, lymphangiomyoma, melanoma, ameloblastoma, craniopharyngioma, mesenchymoma, Hodgkins lymphoma, non-Hodgkins lymphoma, rhabdomyosarcoma, nasal dermoid, seminoma, paratesticular pseudotumor, schwannoma, pleiomorphic adenoma of parotid, adenoid cystic carcinoma of salivary gland, and adrenal tumors. These have been cited by Gorlin et al., ${ }^{53}$ Schulz-Butulis et al., ${ }^{54}$ and Yelmaz et al..$^{55}$ Some have, no doubt, chance association, but these must be carefully documented so that one is able to ascertain what is truly associated with this syndrome and what is aleatory.

\section{GENETICS}

Nevoid basal cell carcinoma syndrome has autosomal dominant inheritance with complete penetrance and remarkably variable expressivity. There is no sexual predilection. About one-half represent new mutations. The mutated gene, Patched, has been mapped to chromosome band 9q22.3.,56 The gene consists of 23 exons and 12 transmembrane-spanning domains coding for two large hydrophilic extracellular loops where Sonic Hedgehog ligand binding occurs. If a mutation occurs in Patched, then the second loop is not formed and Sonic Hedgehog cannot be attached. There have been a few examples of deletion of this area of chromosome 9 inpatients with the syndrome..$^{57} \mathrm{I}$ have personally seen two such individuals who have been severely mentally retarded. 
The widespread developmental abnormalities as well as other neoplasms and overgrowth and loss of heterozygosity at this site suggested mutation of a tumor-suppressor gene. ${ }^{49,58}$ The gene, Patched, which modifies the Hedgehog signaling pathway, is mutated not only in the syndrome but in ordinary isolated basal cell carcinomas. ${ }^{59,60}$ Patched, in the absence of its ligand, Sonic Hedgehog, acts a cell-cycle regulator, normally inhibiting expression of downstream genes (Smoothened, among others), which control cell fate, patterning, and growth ${ }^{61}$ (Fig. 8). In the case of a C-terminal truncation caused by a mutation in Patched, Smoothened is no longer repressed.

In accordance with the Knudson two-hit hypothesis, there is an inherited point (germline) mutation with subsequent loss of its homologue by mitotic nondysjunction, deletion, or mitotic recombination, i.e., random somatic events. In the syndrome, various tumors and hamartomas (basal cell carcinomas, odontogenic keratocysts, meningiomas, ovarian fibromas) exhibit loss of heterozygosity ${ }^{62,63}$ but other lesions do not, for example, palmar pits. ${ }^{64}$ Loss of heterozygosity in the Patched locus has been observed in almost 90\% of hereditary basal cell carcinomas. Various physical anomalies (bifid rib, macrocephaly) apparently need only one hit. The reader is referred to superb detailed reviews of the molecular aspect of this syndrome by Cohen. ${ }^{65,66}$

Analysis of gene mutations in the syndrome indicates deletions, insertions, splice site alterations, and nonsense and missense mutations with no hot spots identified for mutations. About $70 \%$ of germ-line Patched mutations are rearrangements. Over $80 \%$ appear to result in truncation of the Patched 1 protein. ${ }^{67}$ As indicated earlier, the gene is large, consisting of 23 exons which span $34 \mathrm{~kb}$. It encodes a transmembrane glycoprotein composed of 1447 amino acids with 12 hydrophobic transmembrane domains. Using single strand confirmation polymorphism analysis or heteroduplex analysis, only about
$50 \%$ of mutations can be detected. However, Lam et al., ${ }^{68}$ using denaturating high-performance liquid chromatography, found that $90 \%$ of patients had mutations. Prenatal diagnosis has been accomplished. ${ }^{69,70}$

The Hedgehog's signaling pathway is much more involved with regard to (1) Hedgehog's complex with cholesterol and a palmitate moiety (the cholesterol is attached at the C-terminal and the palmitate at the N-terminal) and (2) downstream signaling. An intracellular complex of costal 2, fused, suppressor of fused, and a short form of cubitus interruptus (GLI protein in vertebrates) is tethered to microtubules. Release of this complex from the microtubules is effected by the Hedgehog-cholesterol-palmitate ligand which, in turn, allows transcription of Patched (PTC), Wingless (WNT), and decapentaplegic (BMP) genes. ${ }^{65,66}$ Various disorders related to defects in the extended pathway include Smith-Lemli-Opitz syndrome, Greig cephalopolysyndactyly, Pallister-Hall syndrome, and postaxial polydactyl type A. ${ }^{66}$ Human mutations in both Sonic Hedgehog and Patched have been shown to cause holoprosencephaly. ${ }^{71}$

In the presence of Sonic Hedgehog, the pathway acts in at least two ways to regulate target genes. ${ }^{4}$ One is to activate GLI1/2 transcription factors, and the other is to inhibit formation of GLI repressors, mostly from GLI3 to repressed target genes. ${ }^{72,73}$

Finally, it is noteworthy that about $30 \%$ of those with NBCCS have mutations in $p 53 .^{74}$

I am most pleased with the notion of Editor-in-Chief, Dr. Richard King and his staff, to invite a number of individuals to tell "how it all began." These tales often involve serendipity, as it did in the case of nevoid basal cell carcinoma syndrome. There is also value in discerning how clinicians or basic scientists are led down "wrong" paths and what led the investigators astray. Many of the homely incidents related to a personalized history are lost forever in the mist of time. But these articles

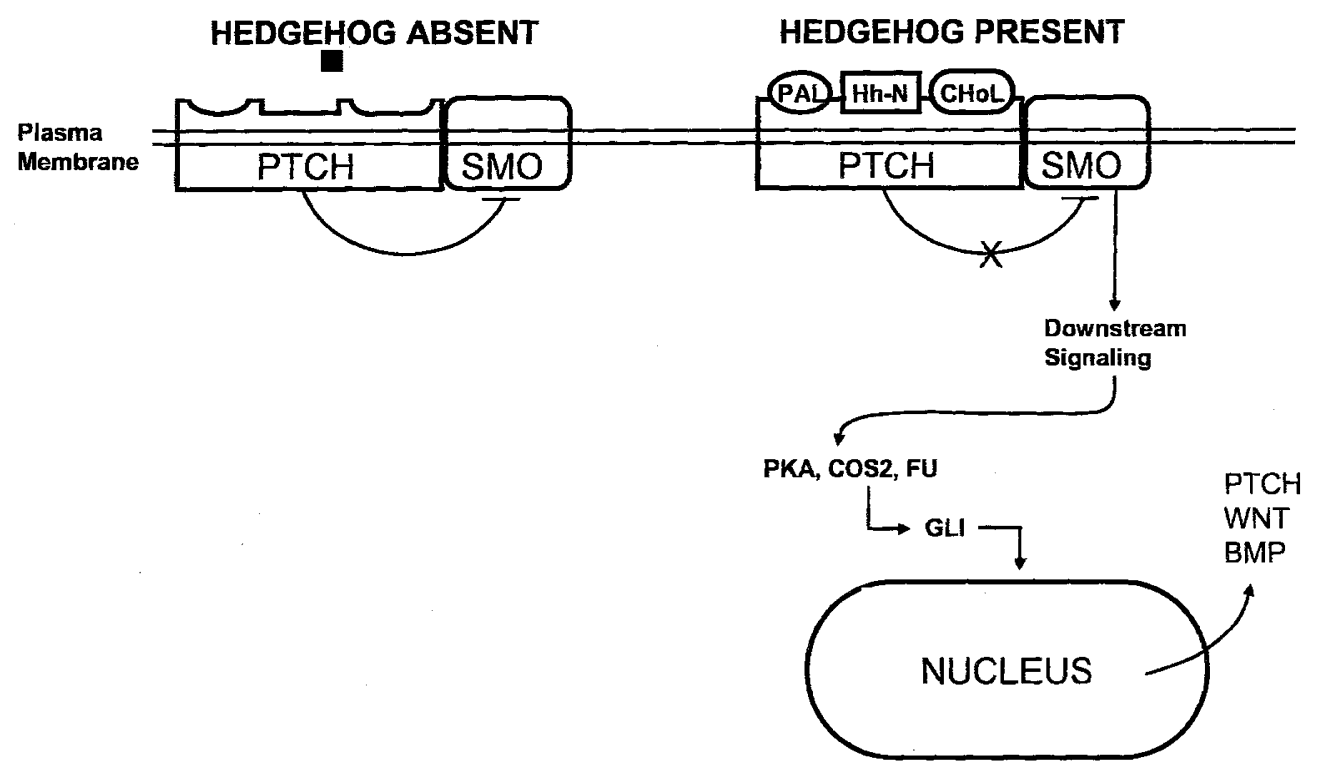

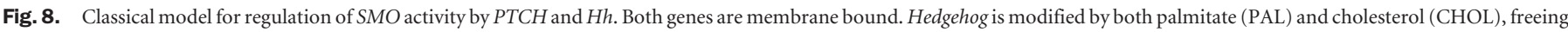
SMO for downstream signaling. (Based on MM Cohen, Jr. Am J Med Genet 2003;123A:5-28.) 
give the "discoverer" the opportunity to sift through one's memory for some of the more colorful stories that otherwise would be buried forever.

\section{References}

1. Gorlin RJ, Goltz R. Multiple nevoid basal cell epitheliomata, jaw cysts, bifid rib-a syndrome. N Engl J Med 1960;262:908-911.

2. Farndon PA, Del Mastro RG, Evans DGR et al. Location of gene for Gorlin syndrome. Lancet 1992;339:581-582.

3. Reis A, Küster W, Linss $G$ et al. Localisation of gene for the naevoid basal-cell carcinoma syndrome. Lancet 1992;339:617.

4. Bale AE, Yu KP. The hedgehog pathway and basal cell carcinomas. Hum Mol Genet 2001;10:757-762.

5. Satinoff MI, Wells C. Multiple basal cell naevus syndrome in ancient Egypt. Med Hist 1969;13:294-297.

6. Maddox WD, Winkelmann RK, Harrison EG et al. Multiple nevoid basal cell epitheliomas, jaw cysts and skeletal defects. JAMA 1964;188:106-111.

7. Rahbari H, Mehregan AH. Basal-cell nevus epithelioma [cancer in children and teenagers]. Cancer 1982;49:350-353.

8. Evans DGR, Birth HM, Orton CI. Brain tumours and the occurrence of severe invasive basal cell carcinoma in first degree relatives with Gorlin syndrome. $\mathrm{Br} J$ Neurosurg 1991;5:643-646.

9. Evans DGR, Farndon PA, Burnell LD et al. The incidence of Gorlin syndrome in 173 consecutive cases of medulloblastoma. Br J Cancer 1991;64:959-961.

10. Pratt MD, Jackson R. Nevoid basal cell carcinoma syndrome. J Am Acad Dermatol 1987;16:964-970

11. Kimonis VE, Goldstein AM, Pastakia B et al. Clinical manifestations in 105 persons with nevoid basal cell carcinoma syndrome. Am J Med Genet 1997;69:299-308.

12. Ruprecht A, Austermann KH, Umstadt H. Cleft lip and palate, seldom seen features of the Gorlin-Goltz syndrome. Dermatomaxillofac Radiol 1987;16:99-103.

13. Soekermann D, Fryns JP, Caesar P et al. Increased head circumference and facia cleft as presenting signs of the nevoid basal cell carcinoma syndrome. Genet Couns 1991;2:157-162.

14. Gorlin RJ. Nevoid basal-cell carcinoma syndrome. Medicine 1987;66:98-113.

15. Evans DGR, Ladusans EJ, Rimmer S et al. Complications of the naevoid basal cell carcinoma syndrome: Results of a population-based study. J Med Genet 1993;30: 462-464.

16. Manners RM, Morris RJ, Francis PJ et al. Microphthalmos in association with Gorlin's syndrome. Br J Ophthalmol 1996;80:378.

17. Shanley S, Ratcliffe J, Hockey A et al. Nevoid basal cell carcinoma syndrome: Review of 118 affected individuals. Am J Med Genet 1994;50:282-290.

18. Goldstein AM, Pastakia B, DiGiovanna JJ et al. 1994. Clinical findings in two African-American families with the nevoid basal cell carcinoma syndrome (NBCC). Am J Med Genet 1994;50:272-281.

19. Winkler PA, Guyuron B. Multiple metastases from basal cell naevus syndrome. $\mathrm{Br}$ Plast Surg 1987;40:528-531.

20. Berardi RS, Korbe J, Melton J et al. Pulmonary metastasis in nevoid basal cell carcinoma syndrome. Int Surg 1991;76:64-66.

21. Camisa C, Rossana C, Little L. Naevoid basal-cell carcinoma syndrome with unilateral neoplasms and pits. Br J Dermatol 1985;113:365-367.

22. Dowling PA, Fleming P, Saunders IDF, Napier SS. Odontogenic keratocysts in a 5-year-old: Initial manifestations of nevoid basal cell carcinoma syndrome. Pediatr Dent 2000;22:53-55.

23. Dominguez FR, Keszler A. Comparative study of keratocysts associated and nonassociated with nevoid basal cell carcinoma syndrome. J Oral Path 1988;17:39-42.

24. Schultz SM, Twickler DM, Wheeler DE et al. Ameloblastoma with basal cell nevus (Gorlin syndrome: CT findings). J Comput-Assist Tomog 1987;11:901-904.

25. Hawegawa K, Amagasa T, Shioda $\mathrm{S}$ et al. Basal cell nevus syndrome with squamous cell carcinoma of the maxilla. J Oral Maxillofac Surg 1989;47:629-633.

26. Meara JG, Shah S, Li KK et al. The odontogenic keratocyst: A 20-year clinicopathologic review. Laryngoscope 1998;108:280-283.

27. Leonardi R, Caltabiano M, LoMuzio L et al. Bilateral hyperplasia of the mandibular coronoid processes in patients with nevoid basal cell carcinoma syndrome. Am J Med Genet 2002;110:400-403.

28. Ratcliffe JF, Shanley S, Ferguson J, Chevenix-Trench G. The diagnostic implication of falcine calcification on plain skull radiographs of patients with basal cell naevus syndrome and the incidence of falcine calcification in their relatives and two control groups. Br J Radiol 1995;68:361-368.

29. Takanashi J, Fujii K, Takano $\mathrm{H}$ et al. Empty sella syndrome in nevoid basal cell carcinoma syndrome. Brain Dev 2000;22:272-274.

30. Ratcliffe JF, Shanley S, Chevenix-Trench G et al. The prevalence of cervical and thoracic congenital skeletal abnormalities in basal cell naevus syndrome: A review of cervical and chest radiographs in 80 patients with BCNS. Br J Radiol 1995;68:596599.

31. Ly JQ. Scintigraphic findings in Gorlin's syndrome. Clin Nucl Med 2002;27:913-914

32. Hawkins JC, Hoffman HJ, Becker LE. Multiple nevoid basal cell carcinoma syndrome (Gorlin's syndrome): Possible confusion with metastatic medulloblastoma. J Neurosurg 1979;50:100-102.

33. Herzberg JJ, Wiskemann A. Die fünfte Phakomatose. Basalzellnaevus mit familiärer Belastung und Medulloblastom. Dermatologica 1963;126:106-123.

34. Amlashi SFA, Riffaud L, Brassier G, Morandi X. Nevoid basal cell carcinoma syndrome: Relation with desmoplastic medulloblastoma in infancy. Cancer 2003;98: $618-624$.

35. Schofield D, West DC, Anthony DC et al. Correlation of loss of heterozygosity at chromosome 9q with histological subtype in medulloblastomas. Am J Pathol 1995 146:472-480.

36. Su CS, Lin KL, Hou JW, Jung SM et al. Spontaneous recovery from a medulloblastoma by a female with Gorlin-Goltz syndrome. Pediatr Neurol 2003;28:231-234.

37. O'Malley S, Weitman D, Olding M et al. Multiple neoplasms following craniospinal irradiation for medulloblastoma in a patient with nevoid basal cell carcinoma syndrome. J Neurosurg 1997;86:286-288.

38. Kantarci M, Ertes U, Alper F, Sutbeyaz Y, Karasen RM, Onbas O. Gorlin's syndrome with a thin corpus callosum and a third ventricular cyst. Neuroradiology 2003;45: $390-392$.

39. Snider RL. Unusual presentation of a third ventricular cyst in a patient with basal cell nevus syndrome. Pediatr Dermatol 1994;11:323-326.

40. Hogan RE, Tress B, Gonzales MF et al. Epilepsy in the nevoid basal cell carcinom syndrome (Gorlin syndrome): Report of a case due to focal neuronal heterotopia. Neurology 1996;46:574-576.

41. Ismail SM, Walker SM. Bilateral virilizing sclerosing stromal tumours of the ovary in a pregnant woman with Gorlin's syndrome: Implications for pathogenesis of ovarian stromal neoplasms. Histopathology 1990;17:159-163.

42. Fox R, Eckford S, Hirschowitz L et al. Refractory gestational hypertension due to a renin-secreting ovarian fibrothecoma associated with Gorlin's syndrome. Br JObste Gynaecol 1994;101:1015-1017.

43. Yoshizumi J, Vaughan RS, Jasani B. Pregnancy associated with Gorlin's syndrome Anaesthesia 1990;45:1046-1048.

44. Kraemer BB, Silver EG, Sneige N. Fibrosarcoma of the ovary: A new component in the nevoid basal cell carcinoma syndrome. Am J Surg Pathol 1984;8:231-236.

45. Seracchioli R, Colombo FM, Bagnoli A, Trengra V, Vanturoli S. Primary ovarian leiomyosarcoma in the nevoid basal cell carcinoma syndrome. Am J Obstet Gynecol 2003;188:1093-1095.

46. Schweisguth O, Gerard-Marchant R, Lemerle J. Naevomatose basocellulaire; association à un rhabdomyosarcome congénital. Arch Fr de Pédiatrie 1968;25:10831093.

47. Dahl E, Kreiborg S, Jensen BL. Craniofacial morphology in the nevoid basal cell carcinoma syndrome. Int J Oral Surgery 1976;5:300-310.

48. Klijanienko J, Caillaud JM, Micheau C et al. Naevomatose basocellulaire associèe a un rhabdomyome foetal multifocal. Presse Med 1988;17:2247-2250.

49. DiSanto S, Abat AB, Boal DK et al. Fetal rhabdomyoma and nevoid basal cell carcinoma syndrome. Pediatr Pathol 1992;12:441-447.

50. Hardisson D, Jimenez-Hafferman JA, Nistal M et al. Neural variant of fetal rhabdomyoma and naevoid basal cell carcinoma syndrome. Histopathology 1996;29:247252

51. Coffin C. Congenital cardiac fibroma associated with Gorlin syndrome. Pediat Pathol 1992;1:255-262.

52. Hogge WA, Blank C, Roochvarg LB et al. Gorlin syndrome (naevoid basal cell carcinoma syndrome): Prenatal detection in a fetus with macrocephaly and ventriculomegaly. Prenat Diagn 1994;14:725-727.

53. Gorlin RJ, Cohen MM Jr, Hennekam RCM. Syndromes of the head and neck. New York: Oxford Univ. Press, 2001.

54. Schulz-Butulis BA, Gilson R, Farley $\mathrm{M}$ et al. Nevoid basal cell carcinoma syndrome and non-Hodgkin's lymphoma. Cutis 2000;66:35-38.

55. Yelmez B, Goldberg LH, Schechter N, Kemp BL, Ruiz H. Basal cell nevus syndrome concurrent with adenomatoid cystic carcinoma of salivary gland. J Am Acad Dermatol 2003;48(5 Suppl):564-566.

56. Wicking C, Shanley S, Smyth I et al. Most germline mutations in the nevoid basal cell carcinoma syndrome lead to premature termination of the PATCHED protein, and no genotype-phenotype correlations are evident. Am J Hum Genet 1997;60:21-26.

57. Shimkets R, Gailani MR, Siu VM et al. Molecular analysis of chromosome 9q deletions in two Gorlin syndrome patients. Am J Hum Genet 1996;59:417-422.

58. Levenat S, Gorlin RJ, Fallet S et al. A two-hit model for developmental defects in Gorlin syndrome. Nat Genet 1996;12:85-87.

59. Aszterbaum M, Rothman A, Johnson RL et al. Identification of mutations in the human PATCHED gene in sporadic basal cell carcinomas and in patients with the basal cell nevus syndrome. J Invest Dermatol 1998;110:885-888. 
60. Villavicencio EH, Walterhouse DO, Iannacone PM et al. The Sonic Hedgehog-PatchedGli pathway in human development and disease. Am J Hum Genet 2000;67:1047-1054.

61. Sidransky D. Is human Patched the gatekeeper of common skin cancers? Nat Genet 1996;14:7-8.

62. Shear M. The aggressive nature of the odontogenic keratocyst: Is it a benign cystic neoplasm? Part 2: Proliferation and genetic studies. Oral Oncol 2002;38:323-331.

63. Barretto DC, Gomez RS, Bale AE et al. PTCH gene mutations in odontogenic keratocysts. J Dent Res 2000;79:1418-1422.

64. Matsumura Y, Nishigori C, Murakami K et al. Allelic loss at the PTCH gene locus in jaw cysts but not in palmar pits in patients with basal cell nevus syndrome. Arch Dermatol Res 2000;292:475-476.

65. Cohen MM Jr. Nevoid basal cell carcinoma syndrome: Molecular biology and new hypotheses. Int J Oral Maxillofac Surg 1999;28:216-233.

66. Cohen MM Jr. The Hedgehog signaling network. Am J Med Genet 2003;123A:5-28.

67. Boutet N, Bignon Y, Drouin-Garraud V et al. Spectrum of PTCH1 mutation in French patients with Gorlin syndrome. J Invest Dermatol 2003;121:478-481.
68. Lam C, Leung C, Lee K et al. Novel mutations in the Patched gene in basal cell nevus syndrome. Mol Genet Metab 2002;76:57-61.

69. Bialer MG, Gailani MR, McLaughlin JA et al. Prenatal diagnosis of Gorlin syndrome. Lancet 1994;344-477.

70. Petrikovsky BM, Bialer MG, McLaughlin JA et al. Sonographic and DNA-based prenatal detection of Gorlin syndrome. J Ultrasound Med 1996;15:493-495.

71. Ming JE, Kaupas ME, Roessler E, Brunner HG, Golabi M, Stratton RF, Sujansky E, Bale SJ, Muencke M. Mutations in Patched-1, the receptor for Sonic Hedgehog, are associated with holoprosencephaly. Hum Genet 2002;110:297301.

72. Ruiz y Altaba A, Sanchez P, Dahmane N. Gli and Hedgehog in cancer: Tumours, embryos, and stem cells. Nature Reviews Cancer 2002;2:361-372.

73. Taipale J, Cooper MK, Maiti T, Beachy PA. Patched acts catalytically to suppress the activity of Smoothened. Nature 2002;418:892-897.

74. Ling G, Ahmadian A, Person A et al. PATCHED and p53 gene alteration in sporadic and hereditary basal cell cancer. Oncogene 2001;20:7770-7778. 